\title{
FIRST RECORD OF FESTUCA AMETHYSTINA L. FROM THE TRANSYLVANIAN BASIN (ROMANIA)
}

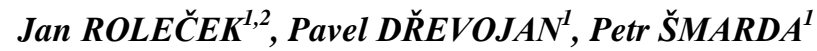 \\ ${ }^{1}$ Department of Botany and Zoology, Faculty of Science, Masaryk University, Kotlářská 2, \\ CZ-611 37 Brno, Czech Republic \\ ${ }^{2}$ Institute of Botany, Czech Academy of Sciences, Department of Vegetation Ecology, Lidická 25/27, \\ CZ-657 20 Brno, Czech Republic \\ e-mail: honza.rolecek@centrum.cz
}

\begin{abstract}
Here we report the first find of a rare grass Festuca amethystina L. in the Transylvanian Basin. The species was found at Dealul Furcilor, a hill that is part of SCI Movilele de la Păucea near the city of Mediaş, in tall-forb vegetation classified as Trollio europaei-Clematidetum recti association. Using flow cytometry we detected tetraploid ploidy level of this population, corresponding to the ploidy of populations in middle altitudes of the Braşov Depression and contrasting with the diploid ploidy level of the high-montane populations in Eastern and Southern Carpathians. We show that sites of tetraploid populations share many species of dry-mesic steppe meadows and subcontinental open-canopy oak forests. Co-occurrence of $F$. amethystina and other species with disjunct distributions suggest relict character of this vegetation, probably representing remnants of ancient foreststeppe ecosystem.
\end{abstract}

Keywords: genome size, plant distribution, ploidy level, relict, tall-forb vegetation, taxonomy, Transylvanian Basin, Trifolio-Geranietea sanguinei, vegetation ecology, vegetation history

\section{Introduction}

Festuca amethystina L. is a grass of open and semi-open habitats with a highly uneven distribution within its range. It is broadly distributed in the montane and subalpine habitats of the Alps, Carpathians and Balkan mountain ranges, while it is scattered or rare elsewhere, particularly in the lowlands and hilly landscapes of Central Europe [16, 22]. It is classified as a rare species in Romania [27] and included in Red Lists also in other countries, e.g. Hungary [17], Czech Republic [10] and Poland [14]. It prefers mesic to dry-mesic grasslands and open canopy forests (mostly Pinus- or Quercus-dominated) on base-rich to moderately base-rich soils, often developed over limestones, other calcareous sediments or ultramafic rocks.

In Romania, $F$. amethystina occurs mainly in the high-montane and subalpine grasslands of the Eastern and Southern Carpathians $[1,5,8]$. Recently it was reported also from submontane open-canopy oak forests of the Braşov Depression [12]. While the high-montane and subalpine populations in Romania seem to be diploid, those in lower altitudes are tetraploid [28]. Although such ploidy differentiation in Festuca usually reflects different taxonomic status [e.g. 15], taxonomic consequences of ploidy variation in $F$. amethystina, particularly the relation to the four recognized subspecies [18, 21], as yet remain unresolved [28].

Here we report the first find of $F$. amethystina in the Transylvanian Basin, together with data on its ploidy and accompanying vegetation. We discuss several related taxonomic and ecological issues in the broad geographical context. 


\section{Material and Methods}

\section{Study area}

Dealul Furcilor (435 m a.s.1.) is situated between the villages Păucea, Blăjel and Romanești, $7 \mathrm{~km}$ north of the city of Mediaş (Sibiu county), in the south-central part of the Transylvanian Basin. The hill is a part of a treeless ridge above the valley of Păucea stream, a tributary of Târnava Mare river. The ridge is formed of calcareous claystones of Neogene age. On northern slopes, the relief is diversified by landslips. The hill is protected within the Site of Community Importance (SCI) Movilele de la Păucea [23, 38].

Morphology and ploidy level

Festuca amethystina can be easily identified due to the absent awns and the specific anatomical structure of the tiller leaves, particularly the organization of sub-epidermal sclerenchyma strands, forming 3-5 ribs along the whole length of tiller leaf sides. The latter character can be observed even in the field on well-preserved desiccated or dead leaves. Nevertheless, we checked the anatomical structure also in transverse cross sections performed on the middle parts of several leaves, using an Olympus SZ-X7 binocular microscope $(\times 50$ magnification). We further checked the morphological characters given as characteristic for the subspecies $F$. amethystina subsp. amethystina and subsp. orientalis in the latest Romanian key [33].

For the estimation of ploidy level, relative genome size was measured approximatively from the dried leaves of the herbarium voucher using flow cytometry with DAPI fluorescence dye. The procedure and concentration of chemicals follow Šmarda [37], with the exception of using Bellis perennis L. (Asteraceae) as the internal genome size standard. Measurements were done with a Partec ML flow cytometer equipped with UV LED diode (Sysmex).

\section{Vegetation composition}

Vegetation data were recorded in a $4 \times 4 \mathrm{~m}$ plot using standard phytosociological methodology, with the extended Braun-Blanquet scale used for species cover-abundance estimation [7]. Topsoil was sampled in several places within the relevé, and $\mathrm{pH}$ and conductivity of a mixed sample were measured in aquatic solution using a Hach HQ40d multi meter.

Taxonomic concepts and nomenclature of vascular plant taxa follow Euro+Med PlantBase [9], except for Avenula praeusta and Campanula moravica, for which the concept of Sârbu et al. (2013) was used, and the following species complexes (aggregates): Dianthus carthusianorum agg. (D. carthusianorum, D. giganteiformis, D. giganteus), Ranunculus polyanthemos agg. ( $R$. nemorosus, $R$. polyanthemos), Veronica chamaedrys agg. ( $V$. chamaedrys, V. vindobonensis) and Vicia cracca agg. (V. cracca, V. tenuifolia).

\section{Results}

Festuca amethystina was found in an abandoned tall-forb-rich steppe meadow on the northern slope of Dealul Furcilor near the city of Mediaş during phytosociological sampling on 24 June 2018 (Fig. 1). The relevé and data on site conditions are provided below. Herbarium vouchers from the plant are deposited in the Herbarium of the Masaryk University (BRNU) in Brno. The plant is tufted, without extravaginal shoots, and its tiller leaves are scabrous throughout their length. The $F$. amethystina/Bellis perennis nuclei fluorescence ratio was 2.154 (mean of two measurements) which corresponds to tetraploids based on our unpublished 
measurements of diploid and tetraploid $F$. amethystina populations from the Central Europe, Ukraine and the Balkans.

Romania, Mediaş region, SCI Movilele de la Păucea, Dealul Furcilor, latitude $46^{\circ} 13 ' 35.1 " \mathrm{~N}$, longitude $24^{\circ} 20^{\prime} 24.2^{\prime \prime} \mathrm{E}$ (WGS-84), altitude $400 \mathrm{~m}$ a.s.1., plot size $16 \mathrm{~m}^{2}$, slope inclination $35^{\circ}$, slope aspect $60^{\circ}$, soil $\mathrm{pH} 6.21$, soil conductivity $254 \mu \mathrm{S} / \mathrm{cm}$, cover of herb layer $70 \%$, cover of moss layer 1\%. Authors: J. Roleček, P. Dřevojan, M. Hájek \& P. Hájková.

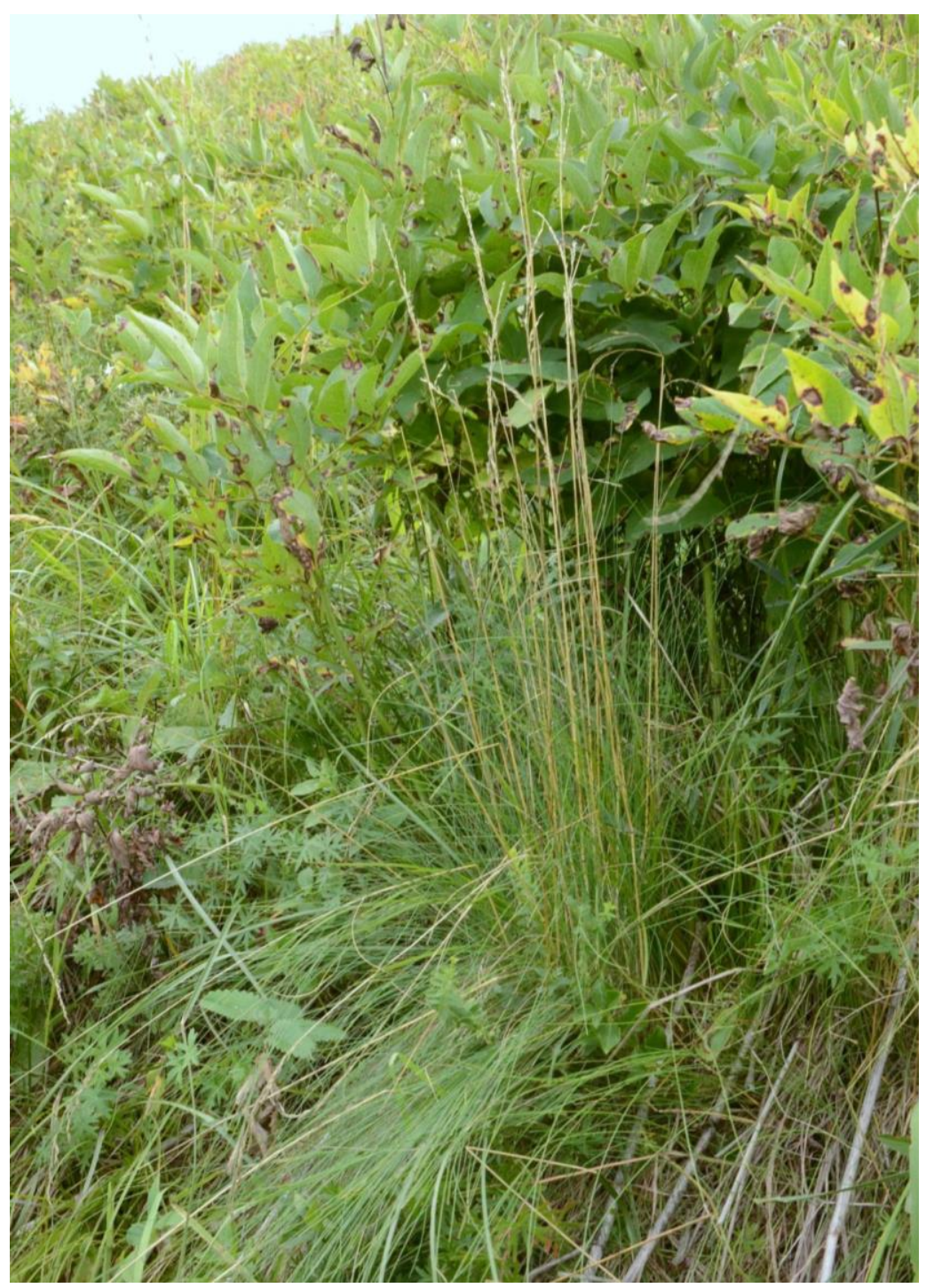

Fig. 1: Festuca amethystina at its newly found site at Dealul Furcilor in the Transylvanian Basin. Tall plants of Clematis recta dominate the stand, and Geranium sanguineum, Mercurialis ovata and Sanguisorba officinalis are also visible.

Herb layer: Clematis recta 3, Carex montana 2b, C. filiformis 2m, Festuca amethystina $2 \mathrm{~m}$, Avenula praeusta $2 \mathrm{~m}$, Stachys officinalis $2 \mathrm{~m}$, Brachypodium pinnatum 1, Ferulago sylvatica 1, Mercurialis ovata 1, Adenophora liliifolia + , Agrimonia eupatoria + , Agrostis capillaris,+ A vinealis +, Allium oleraceum +, Anthericum ramosum +, Anthoxanthum odoratum +, Aristolochia lutea +, Avenula pubescens + , Campanula glomerata,+ C. moravica,$+ C$. persicifolia,+ C. rapunculoides + , Cruciata glabra + , Cytisus albus + , Dactylis glomerata + , Dianthus carthusianorum agg. +, Elytrigia intermedia + , Euphorbia angulata + , Festuca rubra 
+, Filipendula vulgaris +, Galium verum +, Geranium sanguineum +, Gladiolus imbricatus +, Hypochoeris maculata + , Lathyrus pannonicus subsp. collinus + , L. transsilvanicus + , Lilium martagon + , Luzula campestris + , Peucedanum oreoselinum + , Plantago media + , Potentilla alba + , Primula veris + , Prunella grandiflora + , Ranunculus polyanthemos agg. + , Rumex acetosa + , Sanguisorba officinalis + , Schedonorus pratensis + , Securigera varia + , Stellaria graminea +, Tanacetum corymbosum +, Teucrium chamaedrys +, Thesium linophyllon +, Trifolium alpestre +, T. montanum +, T. pannonicum +, Trollius europaeus + , Veronica chamaedrys agg. +, Vicia cracca agg. +, Vincetoxicum hirundinaria +, Carlina acaulis r, Centaurea oxylepis r, Fragaria viridis r, Helleborus purpurascens r, Laserpitium latifolium r, Thalictrum aquilegiifolium r; Crataegus sp. r.

\section{Discussion}

Ploidy level

Tetraploid ploidy level of the $F$. amethystina population at Dealul Furcilor is in agreement with the results of Rewicz et al. (2018), suggesting altitudinal differentiation between high-montane diploids and lower-altitude tetraploids in Romania. The cited study indicates that different ploidy levels cannot be simply associated with any of the four recognized subspecies based on the identification characters currently used. However, the correspondence between the distribution patterns of diploids and F. amethystina subsp. orientalis (Eastern and Southern Carpathians) [21] suggests that Romanian diploids may be probably identified with this subspecies. This view is also supported by diploid ploidy level recorded in a population on Blyznytsya Mt. in Ukrainian Eastern Carpathians (Bednarska \& Šmarda, unpubl.), close to the type locality of F. amethystina subsp. orientalis (Svydovets) [18].

Though the morphology of the plant corresponds clearly to $F$. amethystina subsp. amethystina according to Sârbu et al. (2013), the correct subspecific name for the reported tetraploid population is unclear. This is due to (i) the probable diploid ploidy level of this (nominate) subspecies: the lectotype was designated from Western Alps [3], where diploids of $F$. amethystina are reported by Litardière (1950) and Rewicz et al. (2018); and (ii) unclear taxonomic status of a tetraploid subspecies $F$. amethystina subsp. ritschlii, reported from Central Europe [21], but presently accepted only in Poland [24] and Germany [13].

\section{Vegetation}

Our record is in line with a growing body of evidence that the current distribution of $F$. amethystina reflects not only its habitat requirements, but also long-term history of its sites. It has been hypothesized long ago that low-altitude sites of $F$. amethystina have refugial origin and the species is a glacial or early Holocene relict $[35,36]$. Indeed, perhaps all new records of $F$. amethystina in low and middle altitudes of Central Europe [e.g. 12, 19, 26, 32] come from similar habitats: either subcontinental open-canopy oak forests (Potentillo albae-Quercetum association and closely related communities) or semi-dry and intermittently wet grasslands (Cirsio-Brachypodion and Molinion alliances). That is habitats whose species-pool is believed to be inherited from glacial or early Holocene hemiboreal forest-steppe communities [4, 11, 29]. This hypothesis is supported by the occurrence of species with disjunct distributional ranges in the preserved stands: at Dealul Furcilor, Adenophora liliifolia and Lathyrus transsilvanicus can be mentioned besides $F$. amethystina. 
Although tall-forb-rich steppe is a habitat as yet unreported for $F$. amethystina, it has many features in common with other low-altitude sites of the species. For example, Indreica (2007) reports ten species shared with our relevé from subcontinental open-canopy oak forests in the Braşov Depression: Brachypodium pinnatum (dominant), Campanula glomerata, $C$. persicifolia, Carex montana (dominant), Euphorbia angulata, Potentilla alba, Primula veris, Stachys officinalis, Veronica chamaedrys agg. and Vincetoxicum hirundinaria. Almost all these species are characteristic of forest-steppe habitats such as dry-mesic grasslands, forest fringes and open-canopy forests, usually on deep, base-rich soils. As noted before [2, 30, 34], tall-forbrich steppe meadows are a regular component of forest-steppe mosaics at relatively wet and productive sites (northern slopes, terrain depressions), where conditions are suitable also for species more abundant at higher altitudes or latitudes (at Dealul Furcilor, besides F. amethystina also Aconitum variegatum or Trollius europaeus). In the past such vegetation was possibly more common in the montane or northern forest-steppe.

Remarkably, the phytosociological association Trollio europaei-Clematidetum recti, encompassing tall-forb-rich steppe meadows, was firstly described exactly from Dealul Furcilor [38]. The authors put the association into the Calthion alliance and Molinio-Arrhenatheretea class, which is clearly erroneous. Based on its physiognomy (dominance of tall forest-steppe herbs) and the occurrence of many diagnostic species (e.g. Anthericum ramosum, Brachypodium pinnatum, Carex montana, Campanula persicifolia, Clematis recta, Euphorbia angulata, Ferulago sylvatica, Geranium sanguineum, Laserpitium latifolium, Lathyrus pannonicus subsp. collinus, L. transsilvanicus, Peucedanum oreoselinum, Tanacetum corymbosum, Trifolium alpestre) [25], we classify it within the Trifolio-Geranietea sanguinei class. According to our experience, similar vegetation is scattered over a large area in Transylvania and beyond [30, 31]. Several syntaxa names introduced later (particularly Clematido recti-Laserpitietum latifolii Schneider 1984 and Clematido-Avenuletum praeustae pubescentis subass. clematido rectilaserpitiosum latifolii Bădărău 2005) may be considered synonymous with TrollioClematidetum. Unlike Coldea et al. (2012), we consider the latter name validly published, oldest and therefore correct name for the respective vegetation type.

Acknowledgements: We thank Michal Hájek and Petra Hájková for their help with relevé recording, Lucie Horová for conducting flow cytometry measurements, Adrian Indreica for valuable comments and help with literature retrieval, Anna Szabó for help with literature retrieval and Wolfgang Willner for the advice on phytosociological nomenclature. Jan Roleček was partly supported by the long-term developmental project of the Czech Academy of Sciences (RVO 67985939).

\section{REFERENCES}

1. Andrei, M., 1963, Asociaţia de Festuca amethystina din Munţii Ciucului, Comunic. Acad. R. P. R., 13 (6): 541 550 .

2. Bădărău, A.S., 2005, Transformation of the landscapes within the Transylvanian Plain (Romania) with special focus upon the biogeographical aspects, Ph.D. thesis, Babeș-Bolyai University, Cluj-Napoca, Romania.

3. Cafferty, S., Jarvis, C.E., Turland N.J., 2000, Typification of Linnaean plant names in the Poaceae (Gramineae), Taxon, 49: 239-260. 
4. Chytrý, M., Danihelka, J., Horsák, M., Kočí, M., Kubešová, S., Lososová, Z., Otýpková, Z., Tichý, L., Martynenko, V.B., Baisheva, E.V.Z., 2010, Modern analogues from the Southern Urals provide insights into biodiversity change in the early Holocene forests of Central Europe, Journal of Biogeography, 37 (4): 767-780.

5. Coldea, G., 1991, Prodrome des associations vegetales des Carpates du Sud-Est (Carpates Roumaines), Documents phytosociologiques, Camerino, 13: 318-521.

6. Coldea, G., Oprea, A., Sârbu, I., Sîrbu, C., Ştefan, N., 2012, Les associations végétales de Roumanie. Tome 2. Les associations anthropogènes, Presa Universitară Clujeană, Cluj-Napoca.

7. Dengler, J., Chytrý, M., Ewald, J., 2008, Phytosociology. In: Jørgensen, S.E., Fath, B.D. (eds.), Encyclopedia of ecology. Vol. 4. General ecology, Elsevier, Oxford, 2767-2779.

8. Doniţă, N., Popescu, A., Paucă-Comănescu, M., Mihăilescu, S., Biriş, I.A., 2005, Habitatele din România, Editura Tehnică Silvică, Bucureşti.

9. Euro+Med, 2006-, Euro+Med PlantBase - the information resource for Euro-Mediterranean plant diversity, http://ww2.bgbm.org/EuroPlusMed/. Accessed 17 December 2018.

10. Grulich, V., 2012, Red List of vascular plants of the Czech Republic: 3rd edition, Preslia, 84 (3): 631-645.

11. Hájková, P., Roleček, J., Hájek, M., Horsák, M., Fajmon, K., Polák, M., Jamrichová, E., 2011, Prehistoric origin of the extremely species-rich semi-dry grasslands in the Bílé Karpaty Mts (Czech Republic and Slovakia), Preslia, 83 (2): 185-204.

12. Indreica, A., 2007, Festuca amethystina in the sessile oak forests from upper basin of Olt River, Contrib.Bot., 42: 11-18.

13. Jäger, E.J., (ed.), 2011, Exkursionsflora von Deutschland. Gefässpflanzen: Grundband. 20th ed., Spektrum Akademischer Verlag, Heidelberg.

14. Kaźmierczakowa, R., (ed.), 2016, Polska czerwona lista paprotników i roślin kwiatowych [Polish red list of ferns and flowering plants], Instytut Ochrony Przyrody, PAN, Kraków [in Polish].

15. Kerguélen, M., Plonka, F., 1989, Les Festuca de la Flore de la France (Corse complice), Bulletin de la Société Botanique du Centre-Ouest, Ser. Nova, 10: 1-368.

16. Kiedrzyński, M., Zielińska, K.M., Kiedrzyńska, E., Jakubowska-Gabara, J., 2015, Regional climate and geology affecting habitat availability for a relict plan in a plain landscape: the case of Festuca amethystina $\mathrm{L}$. in Poland, Plant Ecology \& Diversity, 8: 331-341.

17. Király, G. (ed.), 2007, Vörös Lista. A magyarországi edényes flóra veszélyeztetett fajai [Red list of the vascular flora of Hungary], Saját kiadás, Sopron [in Hungarian].

18. Krajina, V., 1930, Genus Festuca, In: Domin, K., Schedae ad Floram Čechoslovenicam exsiccatam. Centuria II, Acta Botanica Bohemica, 9: 184-220.

19. Lazarski, G., 2016, Festuca amethystina (Poaceae) - nowy gatunek dla flory Płaskowyżu Jędrzejowskiego, Fragmenta floristica et geobotanica polonica, 23 (2): 370-374.

20. Litardière, R. de, 1950, Nombre chromosomique de diverses Graminées, Boletim da Sociedade Broteriana, $2{ }^{A}$ Sér., 24: 79-87.

21. Markgraf-Dannenberg, I., 1980, Festuca L. In: Tutin, T.G., Heywood, V.H., Burges, N.A., Moore, D.M., Valentine, D.H., Walters, S.M., Webb, D.A. (eds.), Flora Europaea 5, Cambridge University Press, Cambridge, $125-153$.

22. Meusel, H., Jäger, E., Weinert, E., 1965, Vergleichende Chorologie der zentraleuropäischen Flora. Vol. 1, Gustav Fischer Verlag, Jena.

23. Miclăuşu, C., Nicoară, A.D., 2014, Raport de mediu pentru plan de management - Situl Natura 2000 ROSCI0118 „Movilele de la Paucea“, Agenția pentru Protecția Mediului Sibiu, http://apmsbold.anpm.ro/upload/135858_Raport de mediu_ Movilele de la Paucea.pdf.

24. Mirek, Z., Piekos-Mirkowa, H., Zajac, A., Zajac, M., 2002, Flowering plants and pteridophytes of Poland. A checklist, W. Szafer Institute of Botany, PAN, Kraków.

25. Mucina, L., Bültmann, H., Dierßen, K., Theurillat, J.-P., Raus, T., Čarni, A., Šumberová, K., Willner, W., Dengler, J., Gavilán García, R., Chytrý, M., Hájek, M., Di Pietro, R., Iakushenko, D., Pallas, J., Daniëls, F.J.A., Bergmeier, E., Santos Guerra, A., Ermakov, N., Valachovič, M., Schaminée, J.H.J., Lysenko, T., Didukh, Y.P., Pignatti, S., Rodwell, J.S., Capelo, J., Weber, H.E., Solomeshch, A., Dimopoulos, P., Aguiar, C., Hennekens, S.M., Tichý, L., 2016, Vegetation of Europe: hierarchical floristic classification system of vascular plant, bryophyte, lichen, and algal communities, Applied Vegetation Science, 19 (Suppl. 1): 3-264. 
26. Nepraš, K., 2010, Květena vrchu Houžetín v Českém středohoří a jeho okolí [Flora of Houžetín hill in the České středohoří Mts and its surroundings], Severočeskou Přírodou, 41: 83-108 [in Czech].

27. Oltean, M., Negrean, G., Popescu, A., Roman, N., Dihoru, G., Sanda, V., Mihăilescu, S., 1994, Studii, sinteze, documentaţii de ecologie. Lista roşie a plantelor superioare din România, Academia Română, Institutul de Biologie, Bucureşti.

28. Rewicz, A., Tomczyk, P.P., Kiedrzyński, M., Zielińska, K.M., Jędrzejczyk, I., Rewers, M., Kiedrzyńska, E., Rewicz, T., 2018, Morphometric traits in the fine-leaved fescues depend on ploidy level: the case of Festuca amethystina L., PeerJ, 6: e5576.

29. Roleček, J., 2007, Vegetace subkontinentálnich doubrav ve střední a východní Evropě [Vegetation of subcontinental oak forests in Central and Eastern Europe], Ph.D. thesis, Masaryk University, Brno, Czech Republic [in Czech, with English summary].

30. Roleček, J., Fajmon, K., Šmarda, P., 2018, Nález hořčíku jestřábníkovitého velkoúborného (Picris hieracioides subsp. umbellata) v NPR Porážky (Bílé Karpaty) a poznámky k jeho výskytu v České republice [Record of Picris hieracioides subsp. umbellata in the White Carpathians and notes on its occurrence in the Czech Republic], Zprávy České botanické společnosti 53 (2): 165-176 [in Czech].

31. Roleček, J., Hájek, M., Dřevojan, P., Prokešová, H., Fajmon, K., Těšitel, J., Daněk, P., Hájková, P., Jongepierová, I., Novák, P., Poluyanov, A.V., Shumska, N.V., Chorney, I.I.: Gradients, species richness and biogeographical links of steppe grasslands in Western Podolia (Ukraine), Phytocoenologia, submitted.

32. Řepka, R., Roleček, J., 2002, Festuca amethystine L. In: Hadinec, J., Lustyk, P., Procházka, F. (eds.), Additamenta ad floram Reipublicae Bohemicae. I. [Additions to the flora of the Czech Republic. I.], Zprávy České botanické společnosti, 37 (1): 78-79 [in Czech].

33. Sârbu, I., Ştefan, N., Oprea, A., 2013, Plante vasculare din România. Determinator ilustrat de teren, Editura Victor B Victor, Bucureşti.

34. Schneider-Binder, E., 1984, Die Waldreben-Laserkraut-Staudenflur (Clematido recti-Laserpitietum latifolii ass. nova) im südsiebenbürgischen Hügelland, Studii şi Comunicări Muzeul Brukenthal Sibiu, Şt. Nat., 26: 143159.

35. Schustler, F.,1918, Xerothermni květena ve vývoji vegetace české. Studie rostlinogeografická [Xerothermic flora in the development of the Czech vegetation. Phytogeographical study], Nákladem vlastním, Praha [in Czech].

36. Szafer, F., 1930, Element górski we florze niżu polskiego [The mountain element in the flora of the Polish Plain], PAU, Kraków [in Polish].

37. Šmarda, P., 2006, DNA ploidy levels and intraspecific DNA content variability in Romanian fescues (Festuca, Poaceae) measured in fresh and herbarium material, Folia Geobotanica, 41: 417-432.

38. Täuber, F., Weber, P., 1976, Dealul cu bulbuci (Trollius europaeus L.) de lîngă Mediaş, Ocrotirea Naturii şi a mediului înconjurător, 20 (1): 23-33.

\title{
PRIMA SEMNALARE PENTRU FESTUCA AMETHYSTINA L. ÎN BAZINUL TRANSILVANIEI (ROMÂNIA)
}

\author{
(Rezumat)
}

Menţionăm pentru prima dată apariţia unei specii rare de graminee, Festuca amethystina L. în bazinul Transilvaniei. Specia a fost găsită pe Dealul Furcilor, care face parte integrată din SCI Movilele de la Paucea, lângă Mediaş, în vegetaţie de ierburi înalte ce aparţine asociaţiei Trollio europaei-Clematidetum recti. $\mathrm{Cu}$ ajutorul citometriei de flux s-a detectat un nivel de tetraploidie în cadrul populaţiei, similar populaţiilor de altitudine medie din Depresiunea Braşovului şi deosebit de diploidia populaţiilor de altitudine înaltă din estul şi sudul Carpaţilor. Demonstrăm că siturile cu populaţii tetraploide adăpostesc multe specii de pajisti stepice mediu-uscate şi de păduri de stejar subcontinentale. Apariţia speciei Festuca amethystina în acest context şi a altor specii cu areal disjunct sugerează caracterul relictar al acestui tip de vegetaţie, reprezentând probabil reminiscenţe ale ecosistemului străvechi de păduri stepice. 